\title{
Stomatal frequency and gas exchange differs in two Blechnum species (Pteridophyta, Blechnaceae) with contrasting ecological breadth
}

\section{La frecuencia estomática e intercambio de gases difieren en dos especies de Blechnum (Pteridophyta, Blechnaceae) con distinto rango ecológico}

\author{
Cristian Atala ${ }^{1,2^{*}}$, Alfredo Saldaña ${ }^{3}$ \& Eduardo Navarrete ${ }^{1}$ \\ 1Departamento de Ciencias y Tecnología Vegetal, Universidad de Concepción, Campus Los Ángeles. Juan Antonio Coloma \\ 0201 Los Ángeles, Chile. \\ 'Laboratorio de Anatomía y Ecología Funcional de Plantas. Universidad de Concepción, Campus Los Ángeles. Juan Antonio \\ Coloma 0201 Los Ángeles, Chile. \\ 32Departamento de Botánica, Universidad de Concepción, Casilla 160-C, Concepción, Chile \\ *catala@udec.cl
}

\begin{abstract}
In Chilean temperate forest, the fern Blechnum chilense has a wide ecological breath, but occur mainly in full sun habitats, while Blechnum mochaenum is restricted only to shady sites. We evaluated if the species with different ecological breath behave similarly in their anatomical and physiological traits. Maximal photosynthetic rate (Amax), Stomatal conductance $\left(g_{s}\right)$, evapotranspiration $(E)$, and SLA (specific leaf area) were measured in situ in 20 individuals of each fern species. Additionally, we estimated the stomatal density (SD), stomatal index (SI), and stomatal size in leaves of each sampled individual. B. mochaenum, the shade-tolerant species, had lower SD, SI, A, and $E$, and higher stomatal size and SLA than $B$. chilense. Higher stomatal frequency could result in greater gas exchange in open sites for $B$. chilense. The leaf physiology of these fern species seems to depend partially on their stomatal traits.
\end{abstract}

KeYwords: Blechnum, stomatal density, stomatal index, stomatal size, gas exchange, evergreen temperate forest.

\section{RESUMEN}

En el bosque templado de Chile, el helecho Blechnum chilense se encuentra principalmente en lugares abiertos y soleados, mientras que el helecho Blechnum mochaenum está restringido a lugares sombríos. En este estudio se evalúa si ambas especies de Blechnum, de lugares abiertos y sombreados, se comportan de manera similar respecto de sus rasgos anatómicos y fisiológicos, y si existe diferencia en la correlación entre estos rasgos. Se midió la tasa fotosintética máxima (Amax), conductancia estomática $\left(g_{s}\right)$, evapotranspiración $(E)$ y SLA (área foliar específica) in situ en 20 individuos de cada especie de helecho. Adicionalmente, se estimó la densidad estomática (SD), el índice estomático (SI) y el tamaño de los estomas en hojas de cada individuo muestreado. Blechnum mochaenum, la especies sombra-tolerante, presentó menor SD, SI, Amax y $E$, y mayor tamaño de estomas y SLA que $B$. chilense. Una frecuencia estomática mayor podría resultar en una mayor tasa de intercambio de gases en los sitios abiertos para $B$. chilense. La fisiología de las hojas de estas especies de helechos parece depender, en parte, de las características estomáticas.

Palabras clave: Blechnum, densidad estomática, índice estomático, tamaño de estomas, intercambio de gases, bosque templado siempreverde.

\section{INTRODUCTION}

Ferns are an old group of vascular plants, first appearing in the Mississipian between 345 and 325 MY (Steward \& Rothwell 1993) and they can be presently found in diverse environments (Raven et al. 1999). These plants originated in a palaeoenvironment with different atmospheric and temperature conditions compared to present. Conditions in the Carboniferous were somewhat warmer and with more atmospheric $\mathrm{CO}_{2}$ and moisture (Steward \& Rothwell 1993). They are dependent on free water for their reproduction, particularly their gametophytic phase (Page 2002). Because of that, they are usually found in shady and moist sites (Page 2002). Their evolutionary past influenced ferns in having 
a poor control of water conductance and stomatal closure in their leaves (Woodhouse \& Nobel 1982, Robinson 1994, Brodribb \& Holbrook 2004). However, some ferns can establish in water-deficient soils (Page 2002) and grow in high-irradiance conditions (Saldaña et al. 2005, 2007).

Water loss control and thermal regulation of leaves is partially achieved in vascular plants by regulating stomata aperture and closure (Taiz \& Zeiger 2002). Stomatal closure is induced by water stress (Cochard et al. 2002), specifically by loss of leaf turgor (Brodribb et al. 2003, Brodribb \& Holbrook 2003) and xylem cavitation (Nardini et al. 2001). In Pteridophyta (Heiser et al. 1996), and particularly in ferns, stomatal closure and responsiveness to water deficit is lower than in angiosperms. Stomatal closure in angiosperms usually correspond with the water potential responsible for $50 \%$ loss of leaf hydraulic conductance $\left(\mathrm{K}_{\text {leaf }}\right)$, and ferns close stomata before $\mathrm{K}_{\text {leaf }}$ start to drop (Brodribb \& Holbrook 2004). Stomatal density (SD) and stomatal size then can be key traits in controlling leaf physiology, particularly in ferns were stomatal closure is badly achieved (Robinson 1994, Schlüter et al. 2003). On the other hand, the proportion of stomata to epidermal cell can also provide a mean to regulate gas exchange in leaves (Schlüter et al. 2003). Stomatal index (SI, stomatal density relative to epidermal cell density) can be used to show the relative investment in stomata per epidermal cell in a determinate leaf (Royer 2001). Thus, higher stomatal size, and stomatal and epidermal cell frequencies (i.e. SD and SI) could result in higher rates of gas exchange (Poole et al. 1996, Royer 2001, Schlüter et al. 2003) due to the greater surface available to gas exchange per unit of leaf area.

Light can also affect SD, and SI in leaves (Furukawa 1997, Zacchini et al. 1997). Furukawa (1997) found a positive relation between both SD and SI and PFD (photon flux density). The light environment of developing leaves could alter stomata differentiation to match the different requirements of shaded and open sited (Schlüter et al. 2003). Thus, plants adapted to shaded environments could differ from open sites species in stomatal frequency parameters (Gay \& Hurd 1975, Schoch et al. 1980). In high irradiance sites higher SD and SI could be selected to achieve high gas exchange rates when water availability is not limiting.

In Chilean evergreen temperate forest, the fern Blechnum chilense (Kaulf.) Mett. occur mainly in full sun, but can occupy a wide range of light environments; while the fern Blechnum mochaenum Kunkel is restricted only to shady and moist sites (Saldaña et al. 2005). We evaluated the following hypothesis: Ferns with different ecological breath should differ in their stomatal frequency and gas exchange. We assessed this proposition by examining these anatomical traits (SD, SI, and stomatal size) and gas exchange parameters (maximal photosynthetic rate (Amax), stomatal conductance $\left(g_{s}\right)$ and evapotranspiration $(E)$ ), in the two congeneric ferns species mentioned above.

\section{MATERIALS AND METHODS}

STUdy SITE AND SPECIES

The study was conducted in the low-altitude forests (350-440 m.a.s.1.) of Parque Nacional Puyehue (40³9'S, $72^{\circ} 11^{\prime} \mathrm{W}$ ) located in the western foothills of the Andean range in southern central Chile. The old-growth rain forest at this altitude on the western foorhills of the Andes is composed exclusively of broad-leaved evergreen species (Lusk et al. 2006).

Blechnum is a fern genus belonging to the Blechnaceae, widely distributed in Chile (Rodríguez 1995) comprising species of different habitat preferences (Saldaña et al. 2005). Blechnum chilense is a native species that can be found in a very broad range of light and moisture conditions, from open gaps with high radiation exposure to the understory with less than 5\% canopy openness (Saldaña et al. 2005). $B$. mochaenum is also a native species but is restricted to shaded and moist sites in the understory, usually found in sites with $1 \%$ canopy openness or less, and is considered to be very shade-tolerant (Saldaña et al. 2005).

Individuals of Blechnum chilense and B. mochaenum were randomly selected from populations of these species growing in contrasting light conditions. Ten meters was the minimal distance between measured individuals, to ensure the independence of samples. B. chilensis occupy a wide range of light environments and it is usually found on open sites (Saldaña et al. 2005). On the other hand B. mochaenum is more restricted in their range and is usually found in the understory (Saldaña et al. 2005). We measured physiological traits (see below) of each individual in the same portion of a random leaf, oriented always in the same direction. The same leaf was collected and photographed for anatomical and area measurements.

FIELD DATA

Maximal photosynthetic rate (Amax), stomatal conductance $\left(g_{s}\right)$ and evapotranspiration $(E)$ were measured in situ in 20 indivividual of each fern species, from shaded understory (0.1-5\% canopy openness) and large gaps ( $>35 \%$ canopy openness). $A, g_{s}$ and $E$ measurements were made using a portable infrared gas analyzer and leaf chamber ( $L c i$, ADCBioscientific, England). Both gas exchange parameters were measured at a PAR of $\sim 200-300 \mu \mathrm{mol} \mathrm{m} \mathrm{m}^{-2}$, at $20^{\circ} \mathrm{C}$ for shade species and at a PAR of $>700 \mu \mathrm{mol} \mathrm{m} \mathrm{m}^{-2} \mathrm{~s}^{-1}$, at $20^{\circ} \mathrm{C}$ for sun species, corresponding to the natural light environment of each fern species. We could not obtain maximal photosynthesis rate since the IRGA did not have a light source. These measurements were carried out in midgrowing season (from October $10^{\text {th }}$ to $15^{\text {th }}$ ) on two fully expanded leaves per plant. All gas exchange measurements were conducted between 9:00 and 11:00 AM. We used the average of the 20 measured individuals to obtain species trait value. Leaf area was measured from the digital images 
using image software (SigmaScan pro5, SSI, California, USA).

Stomatal Density, STOMATAL INDEX, AND STOMATAL SIZE Three subsamples of tissue were collected from a single leaflet collected from the middle of the leaf of each plant. The subsamples corresponded to the base, the middle section, and the tip of the leaflet. This was done to incorporate the spatial variation that may exist within a single leaflet. All stomatal measures were made in the abaxial side of the laminas. Each subsample was submerged in commercial chloride to make the tissue transparent. All samples were stained with methylene blue and photographed with a digital camera attached to a stereomicroscope (Nikon, Fukuoka, Japan). Digital photos were taken at $100 \mathrm{x}$ and $400 \mathrm{x}$ magnification. Stomata density was estimated counting the number of stomata in a square area $\left(0.5-1 \mathrm{~mm}^{2}\right)$ using SigmaScan Pro5 software (SSI, California, USA). Because epidermal cells were usually irregular, epidermal cell density was estimated by carefully measuring the area occupied by a certain number of epidermal cells ( $>20$ cells per image). The epidermal cells and the stomata were morphologically similar in both species (Fig. 1). Stomatal size was also measured using SigmaScan Pro5 software (SSI, California, USA). The measurements of each subsample were averaged to obtain the sample value. Stomatal size was measured using the same image software mentioned above.

Stomatal Index was estimated as follow:

Stomatal Index $=($ Stomata density/(Stomata density + epidermal cell density)) x 100

\section{DATA ANALYSIS}

A t-test was applied in order to test interspecific differences in all traits for the two fern species (Blechnum chilense and B. mochaenum).

\section{RESULTS}

Despite the morphological similitude (Fig. 1), there were differences in stomatal density, stomatal index and stomatal area between species studied species of Blechnum differing in their distribution in the light gradient (Fig. 2). There were significant differences between $B$. mochaenum (shade tolerant) and $B$. chilense (open site species) in SLA, Amax, and evapotranspiration $(E)$ (Table I, t-test $\mathrm{p}<0.05$ ). However, there was no difference in $g_{s}$ between species (Table I, t-test $\mathrm{p}>0.05$ ).

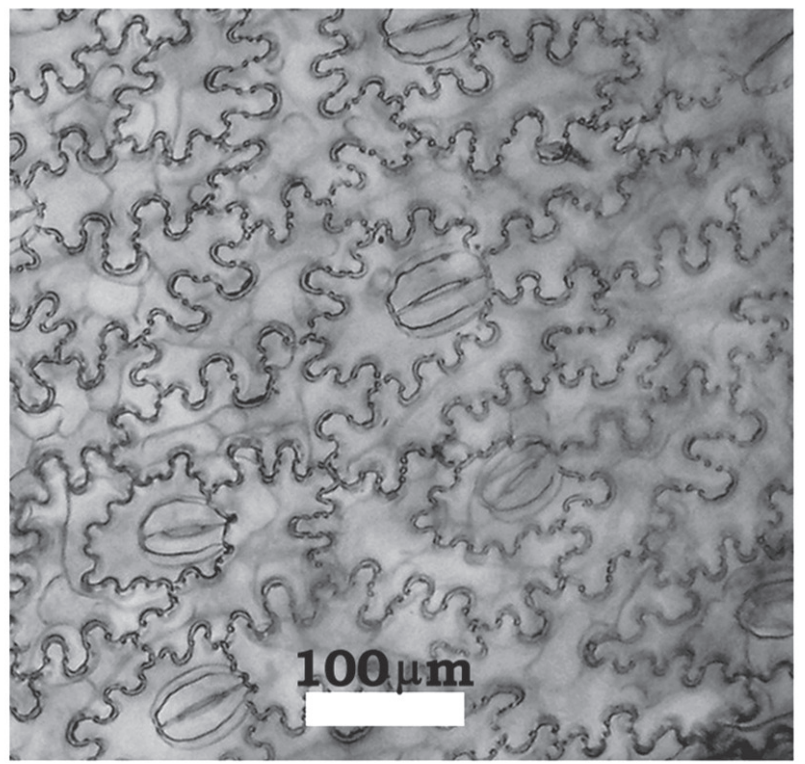

Blechnum mochaenum

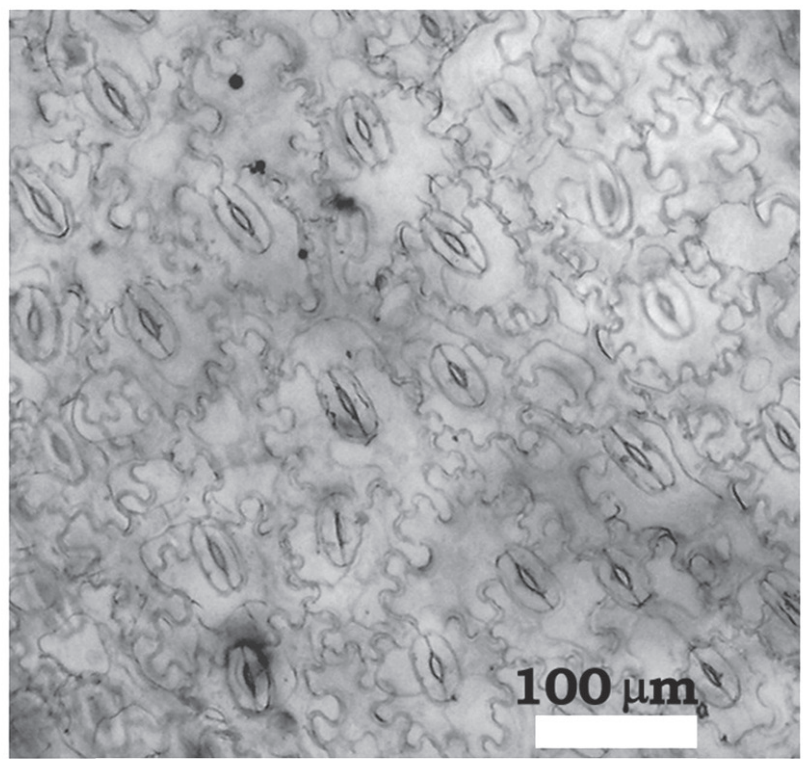

Blechnum chilense

FigURE 1. Microscopy image of the epidermis of Blechnum mochaenum and B. chilense showing stomata and epidermal cells.

Figura 1. Microfotografía de la epidermis de Blechnum mochaenum y B. chilense mostrando los estomas y las células epidérmicas. 
TABLE I. Average ( $\pm \mathrm{SE}$ ) of ecophysiological traits of Blechnum mochaenum and B. chilense growing in an evergreen temperate forest. Type is referred as to the distribution in the light gradient, SLA $=$ specific leaf area, $g_{s}=$ stomatal conductance, $E=$ evapotranspiration, Amax $=$ maximal photosynthetic rate. Asterisk show significant differences among species $\left({ }^{*} \mathrm{p}<0.01,{ }^{* *} \mathrm{p}<0.001\right.$, t-test $)$. SLA and $E$ were Ln-transformed for the statistical analysis. Un-transformed data is shown.

Tabla I. Promedio $( \pm \mathrm{DE})$ de rasgos ecofisiológicos de Blechnum mochaenum y B. chilense creciendo en un bosque templado siempreverde. Type (tipo) se refiere a la distribución en el gradiente lumínico, SLA = área foliar específica, $g_{s}=$ conductancia estomática, $E=$ evapotranspiración, Amax $=$ tasa fotosintética máxima. El asterisco indica diferencias significativas entre especies $(* \mathrm{p}<0.01, * * \mathrm{p}<$ 0.001 , test de $\mathrm{t}$ ). SLA y $E$, se transformaron ( $\mathrm{Ln}$ ) para el análisis estadístico. Se muestran los datos no-transformados.

\begin{tabular}{|c|c|c|c|c|c|c|}
\hline Species & TYPE & $\begin{array}{c}\text { SLA } \\
\left(\mathrm{cm}^{2} \mathrm{~g}-1\right)^{* *}\end{array}$ & (mol & $\left.\mathrm{m}^{2} \mathrm{~s}^{-1}\right)$ & $\begin{array}{c}\mathrm{E} \\
\left(\mathrm{mmol} \mathrm{H}{ }_{2} 0 \mathrm{~m}^{2} \mathrm{~s}^{-1}\right)^{* *}\end{array}$ & $\underset{\left(\mu \mathrm{mol} \mathrm{CO} \mathrm{CO}_{2} \mathrm{~m}^{2} \mathrm{~s}^{-1}\right) *}{*}$ \\
\hline Blechnum mochaenum & shade-tolerant & $289.95 \pm 16.12$ & 0.104 & \pm 0.010 & $0.655 \pm 0.035$ & $4.1 \pm 0.2$ \\
\hline Blechnum chilense & wide-range & $185.92 \pm 34.29$ & 0.119 & \pm 0.007 & $1.382 \pm 0.197$ & $6.7 \pm 0.3$ \\
\hline
\end{tabular}
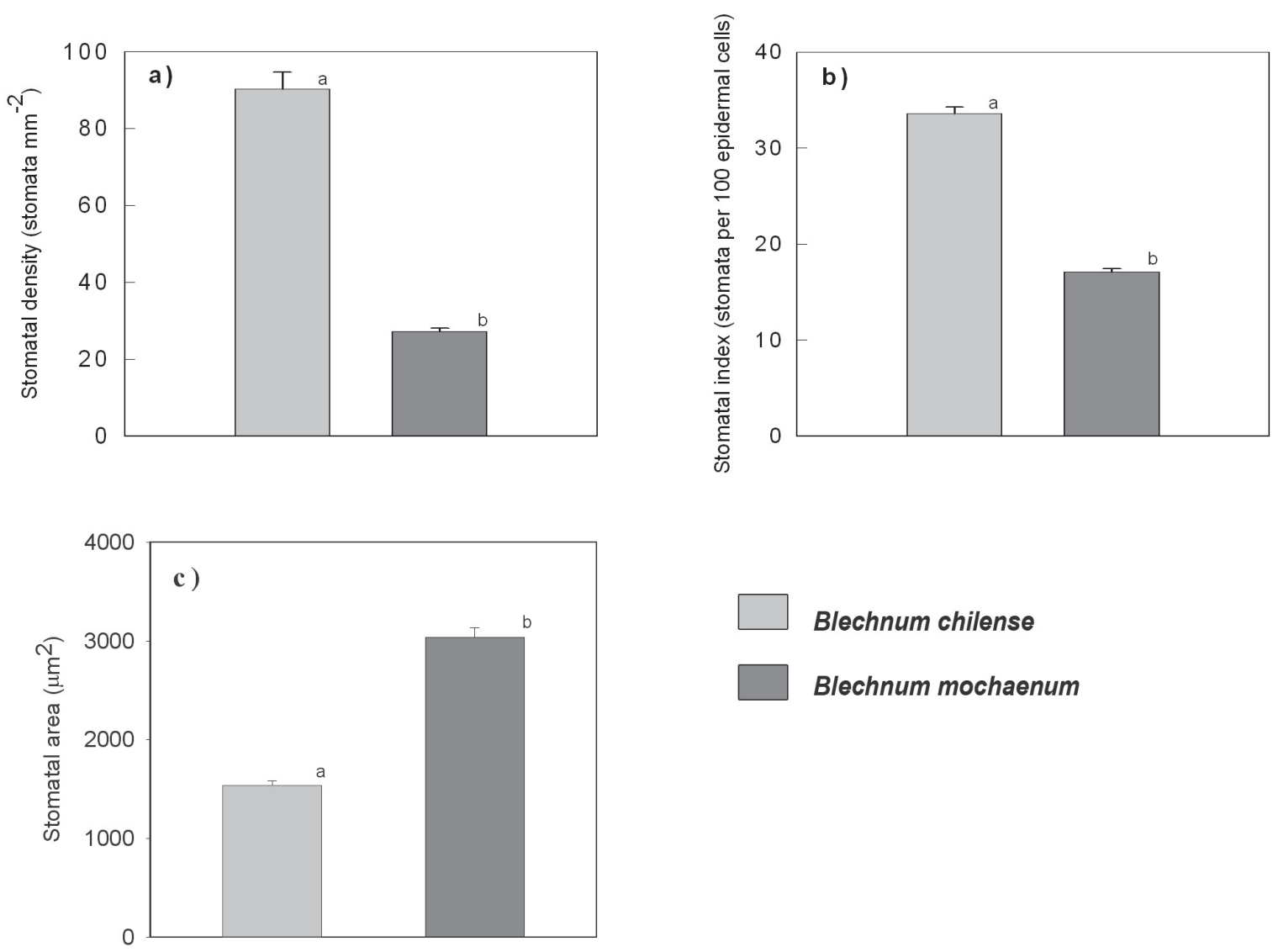

Blechnum chilense

\section{Blechnum mochaenum}

Figure 2. Average ( \pm SE) of stomatal density (a), stomatal index (b, stomata per 100 epidermal cells) and stomatal area (c) of two fern species, Blechnum chilense and B. mochaenum growing in an evergreen temperate forest. Different letters above bars indicate significant differences (For figure a and $\mathrm{b}$, t-test, $\mathrm{p}<0.001$. For $\mathrm{c}$, Wilcoxon test $\mathrm{p}<0.001$ ).

Figura 2. Promedio ( \pm DE) de la densidad estomática (a), índice estomático (b, estomas por 100 células epidérmicas) y área de estoma (c) de especies de helechos, Blechnum chilense y B. mochaenum del bosque templado siempreverde. Letras diferentes sobre las barras indican diferencias significativas (Para figuras a y b, test de $t, p<0.001$. Para $c$, Wilcoxon test $p<0.001$ ). 


\section{DISCUSSION}

The differences in trait expression between these fern species (Table I) are in accordance with the functional value ascribed to these traits (Givnish 1988, Lambers et al. 1998, Ackerly et al. 2000). Blechnum chilense (broad range species) showed higher SD and SI than the shade species Blechnum mochaenum. In open sites, leaves could have a higher SD to increase the carbon input (Gay \& Hurd 1975, Schoch et al. 1980, 1988, Givnish 1988). This higher SD was associated with a higher Amax and E. Species from shaded environments, with lower SD, do not need for high investment in stomata since they are light- and not carbon-limited. It has been reported that SD and SI have been also found to increase with PDF (photon flux density) in plants grown at different irradiances (Furukawa 1997). The environmental cues (such as light and $\mathrm{CO}_{2}$ ) are sensed by expanded leaves, and newly formed leaved should be build accordingly adjusting their SD and SI (Brownlee 2001). This within species trend could hold for between species comparison and plants grown in sun or shade would adjust their stomatal traits accordingly. Stomatal size also varied between species. B. mochaenum had larger stomata compared to $B$. chilense. This difference in size could account for the similar $\mathrm{g}_{\mathrm{s}}$ in both species, despite their difference in SD and SI. Stomatal size seems to be under low environmental control in Blechnum, and depends mainly on the species (Gabriel y Galán et al. 2011). This suggest that given stomatal size is internally regulated (Gabriel y Galán et al. 2011), and that stomatal size affects SD and SI (in the same area, few stomata can be fit if the size is increased), and if stomatal size affects gas exchange, our results could be explained by phyllogenetically-related differences and not by the ecological breath of the species.

In our study SD and SI could be driven by moisture and soil water content rather than light. A relation between water availability and light environment is usually found in many ecosystems (Lambers et al. 1998). SI and SD were found to inversely correlate with water availability gradients (Stenglein et al. 2005). Puyehue National Park receives approximately $3500 \mathrm{~mm} /$ year of rain, and the region do not present drought normally (Di Castri \& Hayek 1976). Hence, in our study site, light availability should be the main factor influencing stomatal frequency in the ferns species considered.

Shade-adapted species usually show limited physiological plasticity compared to open site species (Sultan et al. 1998, Saldaña et al. 2005) and they are not able to achieve high gas exchange rates even when exposed to high light (Lambers et al. 1998, Saldaña et al. 2005). In this context, using a forest FACE (free-air $\mathrm{CO}_{2}$ enrichment) experiment with poplar trees, it was determined that $g_{s}$, and not SD or SI, explained the reduction in $E$ and the increase in WUE (water use efficiency) under elevated $\mathrm{CO}_{2}$ (Tricker et al. 2005).
Our results are consistent with the idea that in different light environments plants express traits that maximize net energy capture (Givnish 1988). The open site species $B$. chilense had higher Amax and $E$ and lower SLA on average than B. mochaenum (Table I), but there were no differences between species in stomatal conductance. Species adapted to high irradiances usually show elevated gas exchange and photosynthesis rates (Givnish 1988), being the evapotranspiration highly related to the photosynthetic capacity (Reich et al. 1999). In the shade, plants maintain very low gas exchange rates to minimize water loss when light do not allows for high carbon gain (Givnish 1988). It seems that the differences in gas exchange properties of ferns adapted to different light environments could be partially explained by the structural characteristics of their leaves, particularly the stomatal frequency and size. The SLA followed the expected patter for sun and shade species (Givnish 1988). Shade species usually show greater SLA to increase the light-capturing surface and sun species have lower SLA due to their higher leaf density and more layers of photosynthetic tissue (Givnish 1988).

These Blechnum fern species that coexist in the Chilean evergreen temperate forest differed in ecological breadth in relation to light availability. Their ecophysiological responses to light variation are consistent with interspecific differences in the ability to occupy different light environments (Saldaña et al. 2005). Despite their evolutionary history, ferns seem to compensate their poorer stomatal control to achieve responses similar to angiosperms. Ferns from different light environments seem to differ ecophysiologically and seem to respond very similarly to angiosperms from the same light environment. Morphological traits, like stomatal index and stomatal size are often ignored in ecophysiological studies and could influence plant responses and determine gas exchange capacities. Further studies are needed to unveil the relationship between fern morphology and ecophysiology in sun and shade species.

\section{ACKNOWLEDGEMENTS}

We thank Nicol Fuentes, Cristian Salgado, Matías Vega and Simon Pfanzelt for help with the field sampling.

\section{REFERENCES}

Ackerly, D.D., S.A. Dudley, S.E. Sultan, J. Schmitt, J.S. Coleman, R. Linder, D.R. Sandquist, M.A. Geber, A.S. Evans, T.E. Dawson, \& M.J. Lechowicz. 2000. The evolution of plant ecophysiological traits: recent advances and future directions. Bioscience 50: 979-995.

BrodribB, T.J. \& N.M. Holbrook. 2003. Stomatal closure during leaf dehydration, correlation with other leaf physiological traits. Plant Physiology 132: 2166-2173. 
BrodribB, T.J. \& N.M. Holbrook. 2004. Stomatal protection against hydraulic failure: a comparison of coexisting ferns and angiosperms. New Phytologist 162: 663-670.

Brodribb, T.J., N.M. Holbrook, E.J. Edwards \& M.V. Gutiérrez. 2003. Relations between stomatal closure, leaf turgor and xylem vulnerability in eight tropical dry forest trees. Plant, Cell and Environment 26: 443-450.

Brownlee, C. 2001. The long and the short of stomatal density signals. Trends in Plants Science 6: 441-442.

Cochard, H., L. Coll, X. Le Roux \& T. Ameglio. 2002. Unraveling the effects of plant hydraulics on stomatal closure during water stress in walnut. Plant Physiology 128: 282-290.

Di Castri, F. \& E. Hayek. 1976. Bioclimatología de Chile. Imprenta Editorial Universidad Católica, Santiago, Chile. $161 \mathrm{pp}$.

FurUKaWA, A. 1997. Stomatal frequency of Querqus myrsinaefolia grown under different irradiances. Photosynthetica 34: 195-199.

Gabriel y Galán, J.M., C. Prada, C.H. Rollen, R. Lahoz-Beltra and C. Martínez-Calvo. 2011. Biometry of stomata in Blechnum species (Blechnaceae) with some taxonomic and ecological implications for the ferns. Revista de Biología Tropical 59(1): 403-415.

Galmes, J., J. Flexas, R. Savé \& H. Medrano. 2007. Water relations and stomatal characteristic of Mediterranean plants with different growth form and leaf habits: responses to water stress and recovery. Plant Soil 290: 139-155.

GAY, A.P. \& R.G. HuRD. 1975. The influence of light on stomatal density in the tomato. New Phytologist 75: 37-46.

Givnish, T.J. 1988. Adaptation to sun and shade: a whole plant perspective. Austral Journal of Plant Physiology 15: 63-92.

Heiser, T., A. Giers \& H.W. Bennert. 1996. In situ gas exchange measurements and the adaptation to light regime of three species of Lycopodium. In: J.M. Camus, M. Gibby \& R.J. Johns (eds.), Pteridology in perspective. Kew, Royal Botanical Gardens, UK, pp 599-610.

Lambers, H., F. Chapin \& T. Pons. 1998. Plant physiological ecology. Springer-Verlag, Berlin, Heidelberg, New York, USA. 540 pp.

Lusk, C.H., R.L. Chazdon \& G. Hofmann. 2006. A bounded null model explains juvenile tree community structure along light availability gradients in a temperate rain forest. Oikos 112: 131-137.

Nardini, A., M.T.Tyree \& S. Salleo. 2001. Xylem cavitation in the leaf of Prunus laurocerasus L. and its impact on leaf hydraulics. Plant Physiology 125: 1700-1709.

PAgE, C.N. 2002. Ecological strategies in fern evolution: a neopteridological overview. Review of Palaeobotany and Palynology 119: 1-33.

Poole, I., J.D.B. Weyers, T. Lawson \& J.A. Raven. 1996. Variations in stomatal density and index: implications for palaeoclimatic reconstructions. Plant, Cell and Environment 19: 705-712.

Raven, P.H., R.F. Evert \& S.E. EichHorn. 1999. Biology of plants, 6th edn. W. H. Freeman and Company, New York, USA. 944 pp.

Reich, P.B., D.S. Ellsworth, M.B. Walters, J.M. Vose, C. Gresham, J.C. Volin \& W.D. Bowman. 1999. Generality of leaf trait relationships: A test across six biomes. Ecology 80: 1955-1969.
Robinson, J. 1994. Speculations on carbon dioxide starvation, Late Tertiary evolution of stomatal regulation and floristic modernization. Plant, Cell and Environment 17: 345-354.

Rodríguez R. 1995. Pteridophyta. En: C. Marticorena \& R. Rodríguez, Flora de Chile. Vol. I. Editorial Universidad de Concepción, Concepción, Chile. 351 pp.

Royer, D.L. 2001. Stomatal density and stomatal index as indicators of paleoatmospheric $\mathrm{CO}_{2}$ concentration. Review of Palaeobotany and Palynology 114: 1-28.

Saldaña A., C.H. Lusk, W.L. GonzÁles \& E. Gianoli. 2007. Natural selection on ecophysiological traits of a fern species in a temperate rainforest. Evolutionary Ecology 21: 651-662.

Saldaña, A., E. Gianoli \& C.H. Lusk. 2005. Ecophysiological responses to light availability in three Blechnum species (Pteridophyta, Blechnaceae) of different ecological breadth. Oecologia 145: 252-257.

Schlüter, U., M. Muschak, D. Berger \& T. Altmann. 2003. Photosynthetic performance of an Arabidopsis mutant with elevated stomatal density (sdd1-1) under different light regimes. Journal of Experimental Botany 54: 867-874.

Schoch, C.H., J.C. Lhotel \& B. BRunel. 1988. Variations of stem diameter, leaf stomatal-resistance and net photosynthetic rate in eggplants affected by water-stress. Photosynthetica 22: 477-482.

Schoch, P.G., C. Zinsou \& M. SibI. 1980. Dependence of the stomatal index on environmental factors during stomatal differentiation in leaves of Vigna sinensis L. Journal of Experimental Botany 31: 1211-1216.

Stenglein, S.A., A.M. Arambarri, M.C. Menéndez-Sevillano \& P.A. Balatti. 2005. Leaf epidermal characters related with plant's passive resistance to pathogens vary among accessions of wild beans Phaseolus vulgaris var. aborigineus (Leguminosae-Phaseoleae). Flora 200: 285-295.

Steward, W.N. \& G.W. Rothwell. 1993. Paleobotany and the Evolution of Plants, 2nd ed. Cambridge University Press, UK. $521 \mathrm{pp}$.

Sultan, S., A.Wilczek, D. Bell \& G. Hand. 1998. Physiological response to complex environments in annual Polygonum species of contrasting ecological breadth. Oecologia 115: 564-578.

Taiz, L. \& Zeiger E. 2002. Plant Physiology, $3^{\text {rd }}$ ed. Sinauer Associates, MA, USA. 690 pp.

Teng, N., J. Wang, T. Chen, X. Wu, Y. Wang \& J. Lin. 2006. Elevated $\mathrm{CO}_{2}$ induces physiological, biochemical and structural changes in leaves of Arabidopsis thaliana. New Phytologist 172: 92-103.

Tricker, P.J., H. Trewin, O. Kull, G.J.J. Clarkson, E. Eensalu, M.J. Tallis, A. Colella, C.P. Doncaster, M. Sabatti \& G. TAYLOR. 2005. Stomatal conductance and not stomatal density determines the long-term reduction in leaf transpiration of poplar in elevated $\mathrm{CO}_{2}$. Oecologia 143: 652-660.

Woodhouse, R. \& P. Nobel. 1982. Stipe anatomy, water potentials and xylem conductances in seven species of ferns (Filicopsida). American Journal of Botany 69: 135-142.

Zacchini, M., S. Morini \& C.Vitagliano. 1997. Effect of photoperiod on some stomatal characteristics of in vitro cultured fruit tree shoots. Plant Cell, Tissue and Organ Culture 49: 195-200. 